\title{
DISABLED CITIZENS $\square$ DEFINING THEIR OWN ROLE IN THE POLITICAL PROCESS. AN EMPIRICAL ANALYSIS OF THE ATTITUDES OF DISABLED PEOPLE IN POLAND IN 2002-2014
}

\begin{abstract}
Define our own role in the process of political participation determines the manner of its implementation, and therefore the attitude we adopt the operating entity in the wider political community. This may be the attitude of an active actor co-responsible for the direction and quality of the policy, or lacking a sense of agency. In the case of disabled persons adopt the first of them it is difficult due to both objective barriers associated with perceptual-motor constraints, and because of the subjective, deeply rooted in society and among the disabled themselves, stereotyping ways of thinking about the functioning of this social category in society. Going beyond this scheme requires the realization of the social model of disability, in which persons with disabilities are active participants in social life, contributing to its development.

The aim of the article is to present the dynamics of change in the perception of people with disabilities in Poland, their subjectivity in the political dimension. The analysis will cover issues such as: interest in politics, trust in political institutions and the generalized others, their capacity to co-create the policy. The data used in the empirical analysis is derived from European Social Survey (2002-2014).
\end{abstract}

Keywords: disability, political subjectivity, citizenship, European Social Survey.

\section{Being a citizen: disabled people's subjectivity as a social issue}

Inclusion of disabled people has become one of the most important social issues in contemporary societies, and there are several reasons for this. On the one hand, efforts to increase the social integration of people with disabilities, encourage their professional activation and assure them opportunities for realising their interests and objectives in life equal to their non-disabled counterparts are a consequence of the fundamental values on which democratic and open societies are based. Public policy built on the concept of universal human and citizens' rights must lead to implementation of actions designed to guarantee the rights

*AGH University of Science and Technology; e-mails: tomaslyk@wp.pl; ewamig@agh.edu.pl 
of disabled people, including political ones. The way in which these obligations towards disabled people are fulfilled is intrinsically diverse, dependent on the tradition and legal and political culture of a given society, its institutional order and the recognised ways of enforcing legal and group rights. As a result, realisation of the rights of disabled people is a multidimensional, equivocal process that is not based on obvious and uniform methods.

On the other hand, providing disabled people with the conditions to function normally in society is increasingly becoming not only an ethical obligation and gauge of public morality, but also an economic challenge resulting from demographic trends. Owing to medical advances and the increase in overall prosperity, the proportion of disabled people in the total population is growing steadily, in certain countries amounting to upwards of $10 \%$, or even $20 \%$ of the population (Gąciarz, Bartkowski 2014: 22). This means that continuation of the simple compensatory model of social policy for disabled people is becoming impossible, both because states' financial capacities are being tested but also owing to the increasing awareness that this solution does not satisfy the demands of disabled people and the needs for a lasting improvement in their socio-economic situation.

Both the first and the second group of factors impacting the situation of disabled people make the question of their complete social and political participation a priority area. In this context, citizenship becomes a category permitting a synthetic overview of the major challenges facing public policy towards disabled people. Above all, it makes the issue of activation of disabled people a key problem of public policy. As a starting point we can take Thomas H. Mars hall's (1950) classic conception of citizenship, which recognised three dimensions: civil (equality of personal rights: freedom of speech, conscience and belief, the right to own property and to conclude contracts, right to justice); political (active and passive voting rights, access to public functions, participation in political decisions); and social (rights in society, access to social security). Social integration of disabled people on this basis can be understood as meaning enabling them to fulfil the role of citizen in each of its three aspects. Citizenship entails equality with other members of society in realising one's entitlements, comprising clusters of personal, political and social rights. To be a citizen it is necessary to have the capacity for subjective behaviours, independent formation of our own conduct and controlling the conditions that influence our situation, as well as for influencing other people, groups and institutions significant in determining the possibilities of our own actions and chances for achieving our objectives.

Personal and group subjectivity are important indicators of the situation of disabled people in contemporary societies. To a great extent, the evolution of their socio-economic situation concerns building and extending their subjectivity, overcoming the mechanisms of oppression formed historically in a period when 
more important concerns in disability policy were segregation and isolation of people affected by disability as well as exercising control over them (such as by subjecting them to institutional forms of care, e.g. in closed institutions). This evolution hinges on the civic empowerment of disabled people - enabling and encouraging them to be involved in fulfilling civic roles, including those directly related to policy making and politics - creating, implementing, evaluating and amending it. This approach to the issue of disability is based on efforts to emancipate people in all of the dimensions of their lives by implanting the principles of independent life in terms of housing and everyday service, joint decision making on the scope and costs of rehabilitation and care, professional activation, social participation (support groups, associations) and public activity.

Citizenship began to be recognised as a key dimension of emancipation of disabled people with the famous declaration made by the Union of the Physically Impaired Against Segregation (UPIAS) in the United Kingdom in 1975, which designated new directions for public policy with reference to disabled people (UPIAS 1975). This statement became the premise for formulation of a social model of disability (cf. O li v e r 2009), over the next three decades also becoming a source of the approach to disability based on fundamental human rights manifested in the 2006 UN Convention on the Rights of Persons with Disabilities, which Poland ratified in 2012 (Dz. U. 2012, No. 0, item 1169). The social model of disability denied the validity of questions about what should be done to help the disabled to adjust to the demands of society both in the physical and social dimensions. According to the proponents of the social approach, the key problem was an attempt to answer the question of how society itself was ready to change the expectations of persons with disabilities so that they could join mainstream social life (Shearer 1981: 10). The crucial challenge was to abandon the interpretation of disability exclusively through the prism of health dysfunction (medicalisation of disability) (S i e g l e r, O s m on d 1974; Z o la 1983; C o n rad 1992) for the sake of the broader social interpretation of disability. Medicalisation meant "a process in which more and more aspects of everyday life were under the influence and medical supervision" (Z o la 1983: 295), which resulted in defining disability in terms of individual deficit. On the other hand, the social model treated disability as a social creation. Moreover, dealing with the problems of disability was not supposed to rely upon an appeal to charity or pity, but rather to consist in proper shaping and promoting of civil rights (S h a k e s p e a r e 2010:268). Of the many aspects of the new paradigm of public policy regarding disability, the most important ones that we can mention are those that assume participation of disabled individuals and their organisations in forming and implementing various public support, rehabilitation, activation and integration mechanisms as a condition of their correct construction and increasing their effectiveness in achieving the aim: complete social inclusion of disabled people. UPIAS, as well as numerous researchers and social activists basing their work on a social model, were behind 
the fundamental reworking of the institutional mechanisms of disability policy in the United Kingdom. A similar process took place in many other countries, reflected in the EU strategy towards disability, and on a global scale in the aforementioned UN convention.

There are many dimensions to being a citizen. Some aspects are formal/legal, including the right to subjective action declared by the state and accorded by institutions. This is an absolutely fundamental premise. Yet fulfilling this condition does not mean that a given person or entire category of people will permitted a fully-fledged role as citizen. The civil society constitutes a value which in the normative dimension can be considered as persistent patterns of conduct, among which a prominent place is occupied by a sense of responsibility, solidarity, respect and trust. On the one hand, they constitute a "fundamental element of consciousness," on the other - a substrate for the "creation of networks of civil engagement" (D zi u b k a 1998: 46). Thus, the crucial thing is autonomy (K e a n e 1988: 14), the voluntariness of association (P erez-Diaz 1996: 70-71), good political manners (Hall 2000: 56) and the shared collective self-consciousness - the cognitive and normative one (Shils 1992: 1). Particularly in reference to disabled people, citizen participation is not only respecting the rights and fulfilling duties, there is also the need to remove a series of barriers - e.g. communicative, transport, information - which prevent or restrict access to processes necessary for fulfilling the role of citizen. In the case of political citizenship, this concerns such opportunities as participation in elections and making a valid vote. In Poland, the process of creating the conditions providing for disabled people to have full participation in the voting act took a long time, encountered many obstacles and remain incomplete (mostly for organisational reasons). Yet studies show that the electoral component of citizenship remains the most fundamental one in the social consciousness (cf. Theiss-Morse 1993; Torney-Purta et al., 2001): "in the collective consciousness, voting rights and participation in elections are the most important correlate of democratic citizenship" (R a c i b o r s ki 2011: 120). ${ }^{2}$

Participation in the public sphere, in the process of creation of public policies, and in consultation of general and local law are all issues that demand a solution to many problems connected to forming relations between institutions and the disabled community. Among the key elements of this process are disabled people's attitudes, their awareness of their civil rights and motivation to act in order to be able to enjoy them, and their understanding of the mechanisms leading to effective influence on the political sphere. Research on the process of participation of disabled people in politics in Poland, including public policy consultation processes, shows that they continue to be engaged on a relatively small scale, and that a number of factors have a negative effect on this process on the part of

${ }^{2}$ Yet there is a dissonance between this normative declaration and the attitudes of Poles, as manifested by the steadily high abstention level (cf. R a c i b o r s k i 2011: 120-126). 
public institutions (Bogacz-Wojtanowska 2014: 235-274). This makes it all the more important to trace how people with disabilities themselves perceive their participation in politics, how they define their role in political processes and evaluate their chances of having an impact on this sphere of public life. The aim of the analysis conducted in this article is to identify this state of self-awareness of disabled people in this respect. This self-awareness is an important condition for their activity or the lack thereof, for shaping the capacity, or incapacity, to influence public policy. In succinct terms, this is a critical aspect of whether the citizenship of disabled people has the chance to become a real phenomenon, or will remain only a normative premise.

\section{Premises of analysis of empirical data}

The conditions for understanding one's own role in the process of political participation and decision making are not only individual, but always form part of a broader context: systemic (type of political system), historical (historical moments strengthening or weakening political activity) or social (values shared in society) (S karżyń ska 1999: 21). In the case of disabled people, emphasising the complexity of the factors involved in taking political actions is significant as it helps to go beyond the determinist-medicalised perspective. This approach is often referred to for individuals with disabilities, meaning that their differentiated forms of activity are analysed with reference to their health-related dysfunctions (Oliver, B arn es 2012: 83-88). To avoid this restriction, at the analytical level we decided to compare disabled and non-disabled individuals, in order to, at least to some extent, be able to verify the impact on macro variables - systemic factors affecting all members of a given political community in a similar way. Based on data from the European Social Survey ${ }^{3}$ rounds from 2002 to 2014 (ESS $1-7)$, the main analytical axis referred to a division into respondents with and those without a disability. In making this classification, we used a biological criterion of disablement, understood as a subjective feeling of limitations which for a given person constitute a significant barrier to carrying out basic activities. The indicator for this state was the response to the question: does the subject when performing everyday activities encounter any impediments resulting from a longterm illness, disability, any ailments, or problems of a psychological nature? In order to maximise the specificity of the indicator (the answer to the question), for some of the analyses (descriptive statistics) we only included those people (deemed to be disabled) who responded "yes, a large amount." We omitted those

3 The European Social Survey (ESS) is an academically driven cross-national survey that has been conducted across Europe since 2001. Every two years, face-to-face interviews are conducted with newly selected, cross-sectional samples. The survey measures the attitudes, beliefs and behavior patterns of diverse populations in more than thirty nations. 
who responded "yes, some amount" (returning to this category in the subsequent analyses based on logistic regression models). The reference category for these people were respondents who responded in the negative to the same question. In the comparative analysis we took into account variables connected to both the affective and the behavioural component of attitudes towards one's own role in the political process. In the first case these were: political interest, interpersonal trust, institutional trust, conformism (all rounds of the research) and understanding of politics (2002-2008 rounds), sense of political clientelism (2002) and sense of political empowerment (2014). The declarations concerning specific behaviours (behavioural component) concerned contacting politicians and undertaking social or political organisational activity (all rounds of research).

In the case of the "interest in politics" variable, two categories of subjects were identified - interested ("very much interested" or "fairly interested") and uninterested ("not very interested" or "not at all interested").

Interpersonal trust (to generalised others) was measured using an index created by totalling the values of the variables that are indicators of trust, honesty and reciprocity (the reliability of the index, measured by alpha coefficient, varied between 0.649 in 2004 and 0.714 in 2010).

The level of institutional trust was estimated on the basis of the value of an index deriving from aggregating the values of the variables referring to trust in the parliament, legal system, police, politicians and the European Parliament (2002 edition) as well as political parties (all other rounds of the study). The coherence of the responses (their relatively high correlation) is demonstrated by the high reliability of the measurement constructed in this way (alpha value from 0.841 in 2006 to 0.883 in 2010).

The indicator of a conformist attitude was the total of the values obtained from the six questions representing the "human values scale". In the analysis, we decided to combine the three detailed dimensions proposed by the authors of the study (S chwartz 2014): conformist attitude (belief in the need to follow orders, rules and regulations and desire to avoid conduct that others might regard as inappropriate), attempts to guarantee one's own security (living in a safe environment and avoiding everything that endangers safety, as well as the belief that the authorities should provide protection from all dangers), and attachment to tradition (being modest and humble, not attracting attention to oneself and acting in accordance with family and religious traditions) (alpha values from 0.716 in 2006 to 0.766 in 2008).

Understanding of politics was based on the linked responses to two questions: 1. How often does politics seem so complicated that you can't really understand what is going on?; 2. How difficult or easy do you find it to make your mind up about political issues? (alpha values from 0.625 in 2002 to 0.690 in 2004).

The indicator of political clientelism was the answers to the following questions: 1. Do you think that politicians in general care what people think?; 2. Would you say that politicians are just interested in getting people's votes rather than in people's opinions? (alpha $=0.690)$. 
Political empowerment was measured on the basis of the aggregated values of responses to questions on the extent to which: (1) the political system in the country allows people such as the respondent to speak out on the government's actions; (2) the respondent is capable of active participation in a group engaged in political issues; (3) the political system in the country allows people such as the respondent to influence politics; (4) the respondent is convinced by his/her own capacities, possibilities for participation in politics; (5) politicians consider what people such as the respondent think to be of significance; (6) it is easy for the respondent to participate in politics personally $($ alpha $=0.798)$.

In the behavioural dimension, we used responses to the question of whether in the last 12 months the subject had contacted a politician or (local-) governmentlevel official, and whether he/she was active in a political party or organisation involved in social or political activity or in another type of organisation or association.

\section{Results}

At the first stage of analysis, we compared disabled persons (DP) and nondisabled persons (ND) in terms of the values obtained for the different variables, also recording the changes that took place among the representatives of the two categories over a period of more than a decade (Table 1).

Politics does not enjoy any great interest among either disabled or nondisabled people. Moreover, over the course of more than a decade, no significant changes were observed in this respect, or a significantly higher value for either category. In general, we can remark that in both categories interest in politics is relatively low - to a lesser or greater extent, one third of the people researched were interested in it. In some cases disabled people $(2004,2010)$ and in others their nondisabled counterparts $(2002,2006,2008,2014)$ had apparently higher results, but only in 2012 was the difference in the scale of this interest statistically significant (chi-squared test for $p<0.05$ ), in favour of respondents with a disability.

Trust in generalised others or the moral bond is based on trust (expectation of decent conduct of others towards us), loyalty (obligation to not violate the trust given to us by others and deliver on our obligations) and solidarity (caring for the interests of others and readiness to perform actions on their behalf, even if this infringes our own interests) (S zto m p ka 2007: 36). In the case of Poland this moral bond is relatively weak (the estimated values are lower than the median value of the index, equal to 5). In each round of the research, however, disabled people were characterised by a significantly lower level of this generalised trust $(t$-test for $p<0.05)$ than those without a disability. For the representatives of both categories, the changes in the level of trust over the years covered by the surveys were insignificant, not exceeding 0.7 of a point on a 10 -point scale. 


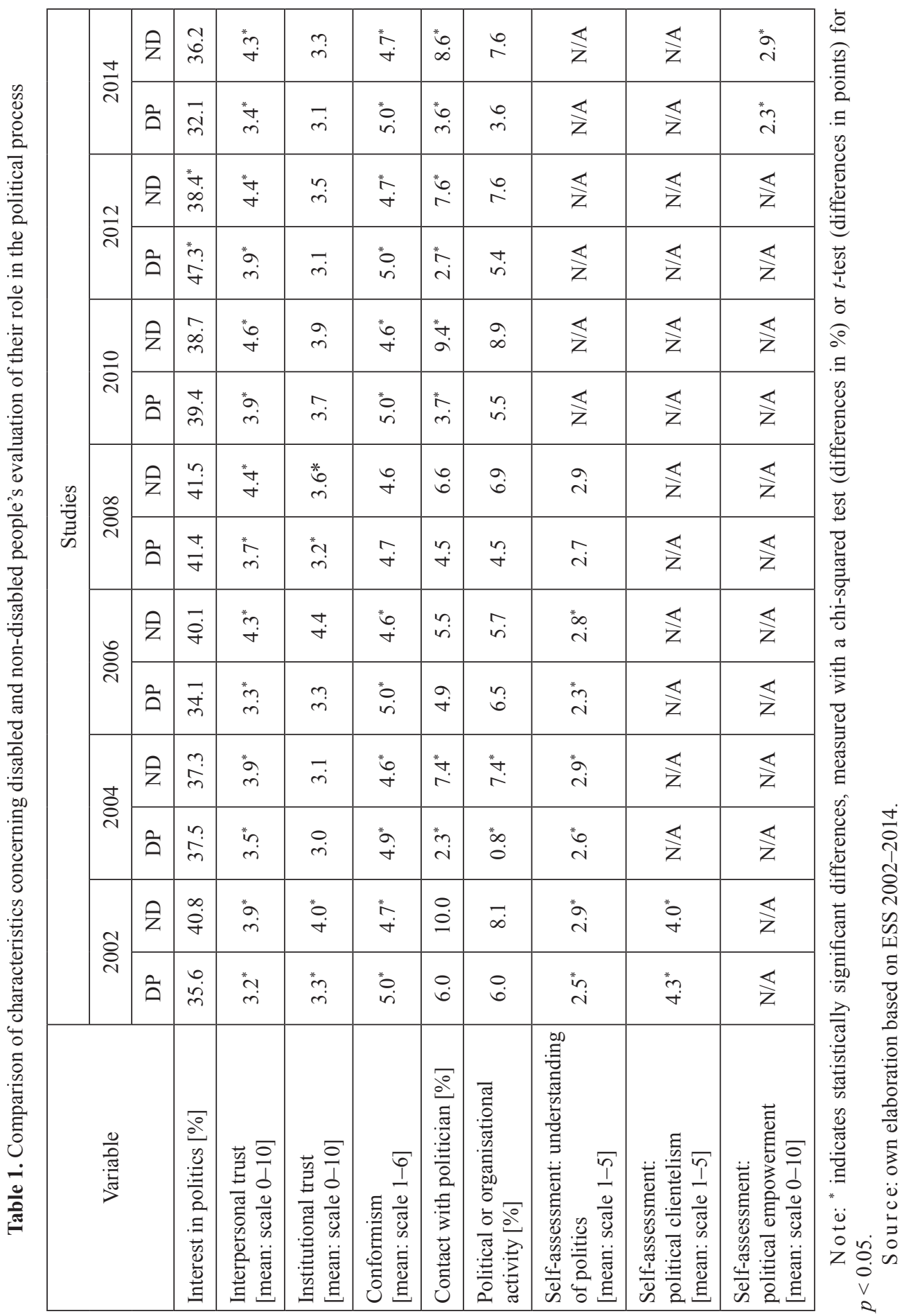


Institutional trust was measured in reference to entities competing for power (political parties and politicians), as well as the legal system and the institutions responsible for establishing the law (national and European parliaments) and those who uphold it (police). The level of institutional trust in Poland is low and relatively stable. The differences in mean values in the various rounds of the study for disabled people did not exceed 0.7 of a point (on a 10-point scale), and for nondisabled people 1.3 points. Furthermore, the two categories did not differ in this respect in the next measurements - a statistically significant difference in favour of people without a disability (a higher level of trust) was recorded only in 2002 and 2008 ( $t$-test for $p<0.05$ ).

Inclination to acting in a conformist way, meaning in keeping with the norms in place (but also tradition and religious rules) as well as avoiding threats and being in favour of the protective role of the state showed significant differences between people with and without disabilities in all rounds of the study ( $t$-test for $p<0.05)$. While the sum of people studied displayed strong conformist attitudes (on average over 4.5 points on an index of 1-6), in comparison with non-disabled people, disabled respondents expressed their stronger conformist attitudes - desire to avoid challenges, uncertain situations and risk and the need for a sense of security and foundation on known and socially established values.

In the behavioural dimension, taking into account the frequency of contacts with politicians and activity in a political party or other social or political organisation, people without a disability are more prominent only in the case of the former type of activity. In this respect, a significant difference in favour of non-disabled people (chi-squared test for $p<0.05$ ) was recorded in the 2004 study and in the three last rounds (2010-2014). However, we should note that contacting representatives of the world of politics is not a popular form of political participation in Poland - it applies to just a few percent of people in the society. It is a similar story with political or social activity. The percentage of people involved has remained at a comparable level over the last decade and more, not exceeding a few percent. Only in the 2004 study was a statistically significant difference between disabled and non-disabled respondents in this regard recorded.

The question about understanding of politics was only asked in the first four rounds of the European Social Survey. In 2002-2006 disabled people significantly more often provided answers indicating that politics is complicated and that it is hard to form one's own opinion on political events ( $t$-test for $p<0.05)$. In 2008 no significant differences were recorded between the representatives of the two categories.

The issue which we call political clientelism was covered only in the first round of the study. In general, the respondents expressed their belief that politicians do not care what ordinary people think, do not want to hear their opinions, and treat them only as suppliers of votes. Participants in the research with a disability presented a significantly more negative attitude in this regard $(t$-test for $p<0.005)$. 
In the final round of the study, in 2014, the respondents were asked several questions whose content was related to the aforementioned issues of clientelism, but some of them also referred to questions of political agency - the extent to which the political system permits active participation in the political process and to which the respondents themselves assess their own possibilities of participating in this process. These issues were treated as indicators of the sense of political empowerment. For Poles as a whole this feeling is extremely weak - the average value on an 11-point scale did not exceed 3. In this regard too, people with a disability displayed significantly greater pessimism ( $t$-test for $p<0.05)$.

If we analyse each of the issues separately, we can conclude that although the declared interest in politics over the 12-year period did not differentiate respondents with and without disabilities, in general the former category felt more alienated in the political system. They were less trusting of other people (in two rounds of the study this lower level of trust also applied to institutions), and it was harder for them to understand political issues, which probably caused them to be more likely to perceive themselves as clients rather than actors of political life. Disabled people are also more withdrawn - conformist, wishing to live modestly and humbly, seeking ways of leading a secure life, something that they think the state can provide. Although this attitude does not translate directly into a significantly lower level of organisational engagement (political or social), it can decide on the way in which they function in this type of organisation. I this context, however, we must ask whether disability itself is a factor differentiating these attitudes, or whether the variables that are immanently connected to disability, above all sociodemographic characteristics such as age, education or income, are also responsible.

To try to find the answer to this question, we used a logistic regression model (separately for each round of research), in which the dependent variable was political interest, and the independent variables were the socio-political variables analysed previously, as well as a set of control (sociodemographic) variables. We also included in the model the variable of "disability", considering the three categories of respondents: those who do not encounter any difficulties in performing everyday activities as a result of long-term illness, disability or problems of a psychological nature (non-disabled), those who face such difficulties to a certain extent (moderate), and those who struggle with them to a great extent (significant).

Over the years, the declared interest in politics remained at a similar level among disabled and non-disabled people, leading us to attempt to ascertain who (and referring to which characteristics) in the two categories was placed on the side of those interested in politics and who on the side of those not interested (Table 2). 


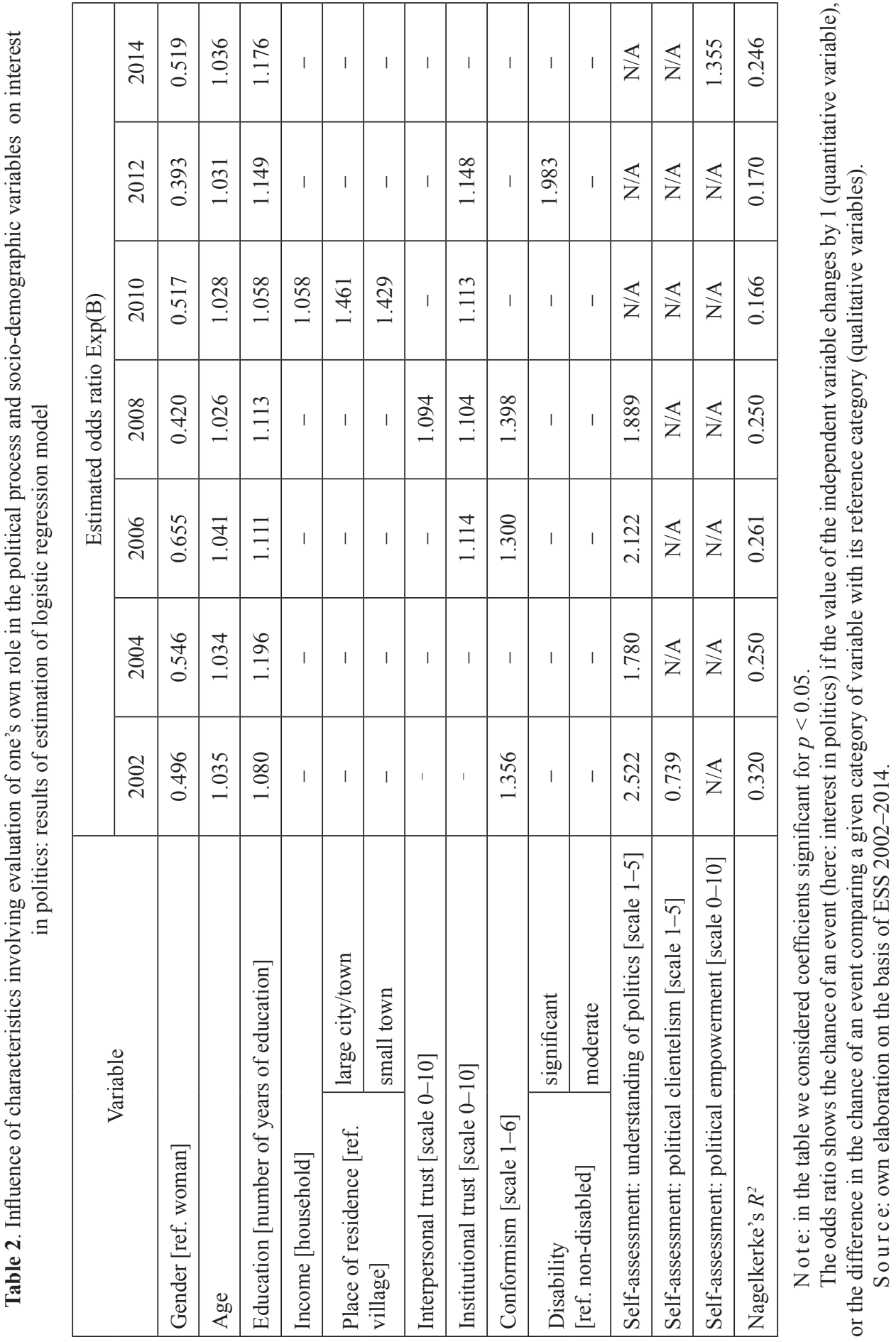


The predictive power of the analysed models is moderate - the Nagelkerke's $R^{2}$ value indicates which part of the variance of the dependent variable is explained by the independent variables included in the model. Referring to the individual rounds of the survey, we can assume that the variables we considered account for the fact of interest (or lack of interest) in politics in one fifth of cases for 2010-2012 (0.166 and 0.170) or one third for 2002 (0.320). The observed difference is certainly caused by the differing number of variables introduced to the model representing the given round of research.

The first and most important observation is that, contrary to the earlier interpretations based on statistical descriptions, disability in itself is not a significant predictor of interest in politics, if other variables are controlled, especially sociodemographic ones. This major influence was recorded only in 2012, in favour of people with a significant disability, for whom the chance of interest in politics was almost twice as high as that among non-disabled people.

The lack of a relationship between disability and interest in politics can be explained by the significant influence of three sociodemographic variables: gender, age and education. This relation is visible at all stages of the research and follows the same model. The probability of interest in politics among women was less than that among men, from $34.5 \%$ in 2006 to $60.7 \%$ in 2012 . Interestingly, the chance of being interested in politics increased with age in such a way that with every year it grew, from $2.6 \%$ in 2008 to $4.1 \%$ in 2006 . Education was the next important predictor of interest in politics - each additional year of education increased this probability, from $8 \%$ in 2002 to $19.6 \%$ in 2004. A significant impact of the remaining sociodemographic variables was only recorded in 2010. The likelihood of interest in politics increased with income, and in terms of place of residence it was greater for residents of small and large towns and cities $(42.9 \%$ and $46.1 \%$ respectively) compared to people living in the country/villages.

The level of trust to generalised others, in all rounds of the survey except for 2008, was not a significant predictor of interest in politics. In 2008 a significant influence of it was recorded - the next value on the scale of trust increased this chance by $9.4 \%$. Institutional trust, meanwhile, was important in four models - between 2006 and 2012. Increase in trust in the institutions making, putting into practice and observing the law meant a rise in the chance of being interested in politics (from 10.4\% in 2008 to $14.8 \%$ in 2012). The last variable used in all models was a conformist attitude. Where a major influence of this variable was recorded (in 2002 and 2006-2009) we can discern a significant, positive influence on interest in politics. In other words, the higher the value obtained on the conformism index, the greater the chance of interest in issues of a political nature (from $30 \%$ for 2006 to $39.8 \%$ for 2008 ).

For the remaining variables, the most obvious predictor of interest in politics was the self-assessment of understanding of politics. In four rounds of the study, when the respondents were able to assess their level of understanding of issues 
of a political nature and describe the amount of difficulty they had in interpreting political events, the chance of interest in politics increases with every point on the scale of understanding politics (from a probability 2.5 times higher in 2002 to one more than 1.5 times higher in 2004). A similar relationship was recorded for the sense of political empowerment in 2014 - with every additional point on the scale of empowerment, the chance of interest in politics rose by $35.5 \%$. The reverse correlation could be observed for the measurement of political clientelism for 2002. The sense of being only a supplier of votes and that politicians themselves are not interested in the opinions of ordinary people reduced the likelihood of interest in political matters (with every point on the scale of clientelism it dropped by $26.1 \%)$.

\section{Conclusion}

In this article we aimed to diagnose the way in which disabled Poles define their role as citizens, but confined ourselves to the political dimension of this category, accepting that "political rights are the quintessence of the narrow understanding of citizenship. They are created so that citizens as members of a political community, acting together or individually, can create the public authorities, exert influence on them and have effective control over them" (R a ciborski 2011: 88). The results of the research prove that in the case of Polish disabled people we can speak rather of deficits in citizenship over the course of the surveyed decade than of civic empowerment, at least in the political dimension. This is because the intensiveness of their political participation is very low, ${ }^{4}$ which is no surprise if we consider this article's outline of the attitudes of disabled people determining their role in the political process. At this point let us recall what the major components of this were, for people both with and without disabilities. Both categories display little interest in politics and are engaged in political and social activity to a minimal extent. Compared to their non-disabled compatriots, though, Poles with disabilities have less interpersonal and institutional trust, have greater difficulties with understanding political issues, are more likely to define themselves as clients, rather than actors in the political process, and are more conformist in their approach, expecting state institutions to offer guarantees of a safe life. As the analysis (based on a logistic regression model) showed, however, the factor differentiating the attitudes of disabled and non-disabled people in the identified spheres is no disability as such, but sociodemographic variables (especially age

${ }^{4}$ It is notable that even the rapid development of the internet in recent years, opening an entirely new field and constructing new ways of participation in politics, has not caused a change in this state of affairs. 
and education), which are immanently associated with disability, which affects mostly older people and less well-educated ones.

It is worth noting in summary that, irrespective of sociodemographic characteristics and the variable of disability, in general in Poland the intensiveness of political participation is low, and citizenship (in the political dimension analysed here) tends to be more passive than engaged. A small consolation might be the fact that Poland is not alone. In fact, "in all democracies in recent years we can observe a drop in civic engagement, at many levels: from participation in elections of political rulers, via the fall in participation in associations, protests and other civic activities, to the lack of even an elementary interest in politics" (R a ciborsk i 2011: 49). To change this state of affairs it is necessary to develop in individuals (disabled or otherwise) the capacity to engage in responsible behaviours, which in turn demand awareness and the need to exert influence on the surrounding reality and to cause changes in them that match our own objectives. Only in this way do citizens gain a subjective, empowered status, conditioned by their own activity - for disabled people this may require adequate assistance, but should not be performed by others instead of them or replaced with institutional or social support. It is such activity that allows citizens to become autonomous, decisionmaking and responsible actors of political and social life.

\section{Bibliography}

Barnes C. (2012), Understanding the social model of disability: past, present and future, [in:] N. Wat s o n,A. R o u 1 s t o n e, C. T h o m a s (ed s), Routledge Handbook of Disability Studies, Routledge, London $\square$ New York, pp. 12-29.

B o g a c z-Wojt a now ska E. (20 14 )Partycypacja polityczna i spoleczna. Niepetnosprawni obywatele w Polsce, [in:] B. G ą c i a r z, S. R u d n i c k i (eds.), Polscy niepetnosprawni. Od kompleksowej diagnozy do nowego modelu polityki spolecznej, Wydawnictwa AGH, Kraków, pp. 235-274.

C o n r a d P. (1992), Medicalization and social control, "Annual Review of Sociology”, Vol. 18, pp. 209-232.

Dziubka K. (1998), Społeczeństwo obywatelskie: wybrane aspekty ewolucji pojęcia, [in:] A. W. Jabłoński, L. S obkowiak (eds), Studia z teorii polityki, Wydawnictwo Uniwersytetu Wrocławskiego, Wrocław, Vol. 2, pp. 31-52.

ESS Round 1-7: European Social Survey Round 1-7 Data (2002-2014), Norwegian Social Science Data Services, Norway - Data Archive and distributor of ESS data for ESS ERIC.

F in k e l s te in V. (1980), Attitudes and disabled people, World Rehabilitation Fund, New York.

G ąc i a r z B., B a rtkow ski J. (2 014$)$ Polożenie spoleczno-ekonomiczne niepetnosprawnych w Polsce na tle sytuacji osób niepetnosprawnych w krajach Unii Europejskiej, „Niepełnosprawność. Zagadnienia, Problemy, Rozwiązania”, No. 2 (11), pp. 20-43.

Hall J. A. (2000), Reflections on the Making of Civility in Society, [in:] F. T r e n t m a n n (ed.), Paradoxes of Civil Society: New Perspectives on Modern German and British History, Berghahn Books, New York, pp. 47-57.

K e a n e J. (1988), Democracy and Civil Society, Verso Books, London. 
Konwencja o prawach osób niepetnosprawnych sporzqdzona w Nowym Jorku dnia 13 grudnia 2006 r., Dz. U. 012, No. 0, item 1169.

Convention on the Rights of Persons with Disabilities (2006), United Nations, available at: http:// www.un.org/disabilities/documents/convention/convoptprot-e.pdf (21.07.2016).

M a r s h 11 Th. H. (1950), Citizenship and Social Class and Other Essays, Cambridge University Press, Cambridge.

Oliver M. (1981), A New Model of the Social Work Role in Relation to Disability, [in:] J. C a m p 1 ing (ed .) The Handicapped Person: A New Perspective for Social Workers?, RADAR, London, pp. 19-32.

Oliv e r M. (1990), The Politics of Disablement, Macmillan, London.

O 1 i v e r M. (2009), Understanding Disability. From Theory to Practice. Second Edition, Palgrave Macmillan, Basingstoke, Hampshire.

O 1 i v e r M., B a r n e s C. (2012), The New Politics of Disablement, Palgrave Macmillan, New York.

P e r e z-D i a z V. M. (1996), Powrót spoleczeństwa obywatelskiego w Hiszpanii, Wydawnictwo Znak, Kraków.

R a c iborski J. (2 01 ), Obywatelstwo w perspektywie socjologicznej, Wydawnictwo Naukowe PWN, Warszawa.

S chwartz Sh. H. (2014), A Proposal for Measuring Value Orientations across Nations: http:// www.europeansocialsurvey.org/docs/methodology/core_ess_questionnaire/ESS_core_ questionnaire_human_values.pdf (4.04.2016).

$\mathrm{S}$ h a k e s p e a r e T. (2 010 ) The social model of disability, [in:] L. J. D a v is (ed.), The Disability Studies Reader, Routledge, New York $\square$ London, pp. 263-277.

Sh e are r A. (1981), Disability: Who's Handicap? Understanding everyday experience, Basil Blackwell, Oxford.

Sh ils E. (1992), Civility and Civil Society, [in:] E. C. B a n fi eld (ed.), Civility and Citizenship in Liberal Democratic Societies, New York: Paragon House, pp. 1-16.

S i e g l e r M.,O s m o nd H. (1 974 Models of Madness: Models of Medicine, Macmillan, New York. S k a r ży ń ska K. (1 999 , )4ktywność i bierność polityczna, [in:] K. S k a ży ń s ka (ed.), Psychologia polityczna, Wydawnictwo Zysk i S-ka, Poznań.

S z t o m p k a P. (2007), Zaufanie. Fundament społeczeństwa, Wydawnictwo Znak, Kraków.

The is s-Mor s e E. (1993) Conceptualizations of Good Citizenship and Political Participation, "Political Behavior", Vol. 15, No. 4, pp. 355-380.

Torney-Purta J., Lehmann R., Oswald H., Schultz W. (2 001 ) Citizenship and Education in Twenty-eight Countries. Civic Knowledge and Engagement at Age Fourteen, The International Association for the Evaluations of Educational Achievement, Amsterdam: http:// www.iea.nl/fileadmin/user_upload/Publications/Electronic_versions/CIVED_Phase2_Age_ Fourteen.pdf (16.07.2016).

UPIAS - Union of the Physically Impaired Against Segregation (1975), The Fundamental Principles of Disability, http://www.leeds.ac.uk/disability-studies/archiveuk/UPIAS/fundamental\%20 principles.pdf (21.07.2016).

Z o la I. K. (1983), Socio-Medical Inquiries: Recollections, Reflections, and Reconsiderations, Temple University Press, Philadelphia. 
Tomasz Masłyk, Ewa Migaczewska

\section{NIEPEŁNOSPRAWNY OBYWATEL $\square$ DEFINIOWANIE WŁASNEJ ROLI W PROCESIE POLITYCZNYM. ANALIZA EMPIRYCZNA POSTAW POLSKICH NIEPELNOSPRAWNYCH W LATACH $2002 \square 2014$}

Streszczenie. Definiowanie własnej roli w procesie uczestnictwa politycznego decyduje o sposobie jej realizacji, a zatem o postawie, jaką przyjmie działający podmiot w szeroko rozumianej wspólnocie politycznej. Może to być postawa aktywnego aktora współodpowiedzialnego za kierunek i jakość realizowanej polityki lub pozbawionego poczucia sprawstwa klienta. W przypadku osób niepełnosprawnych przyjmowanie pierwszej z nich jest utrudnione zarówno ze względu na obiektywne bariery związane z percepcyjno-motorycznymi ograniczeniami, jak i z uwagi na subiektywne, głęboko zakorzenione w społeczeństwie i wśród samych niepełnosprawnych stereotypizujące sposoby myślenia o funkcjonowaniu tej kategorii społecznej w społeczeństwie. Wyjście poza ten schemat wymaga urzeczywistnienia społecznego modelu niepełnosprawności, w którym osoby niepełnosprawne stają się aktywnymi uczestnikami życia społecznego, przyczyniając się do jego rozwoju.

Celem wystapienia jest zaprezentowanie dynamiki zmian w zakresie postrzegania przez osoby niepełnosprawne w Polsce ich podmiotowości w wymiarze politycznym. Analizie poddane zostaną takie kwestie, jak: zainteresowanie polityką, zaufanie do instytucji politycznych i uogólnionych innych oraz własny potencjał w zakresie współkreowania polityki. Dane, do których odwołają się referenci, pochodzić będą z Europejskiego Sondażu Społecznego (2002-2014).

Słowa kluczowe: niepełnosprawność, podmiotowość polityczna, obywatelstwo, Europejski Sondaż Społeczny. 